\title{
DETERMINANTY POPYTU NA UBEZPIECZENIA INDEKSOWE W ROLNICTWIE W ŚWIETLE BADAŃ
}

\section{WPROWADZENIE}

W przypadku gospodarstwa rolnego występuje wysoka różnorodność zagrożeń mających w dużej mierze egzogeniczny charakter i cechujących się ograniczoną możliwością kontroli. Z tego względu dostęp do instrumentów pozwalających na finansowanie skutków materializacji tych zagrożeń ma znaczenie kluczowe, niezależnie od postawionego przez gospodarstwo celu (przetrwanie lub rozwój). Jednym z instrumentów kontroli finansowej są ubezpieczenia, w tym ubezpieczenia upraw.

Ubezpieczenia upraw, niezależnie od rynku, na którym są oferowane, oparte były od początku na zasadzie odszkodowawczej, która stanowiła, że wypłacane odszkodowanie pokrywało zaistniałą z umówionych przyczyn szkodę (przy czym, tak jak w innych rodzajach ubezpieczeń, dopuszczalne były różne formy ograniczania odpowiedzialności ubezpieczyciela). Ze względu jednak na wysoki poziom kumulacji ryzyka, problemy z dostępnością i wysoką cenę reasekuracji, poziom asymetrii informacji, skutkujacy podwyższonym hazardem moralnym i motywacyjnym, a także kosztowną i wymagająca specjalistycznej wiedzy likwidację szkód, której towarzyszą liczne spory - koszty funkcjonowania tradycyjnych ubezpieczeń upraw były bardzo wysokie ${ }^{1}$. To zrodziło potrzebę poszukiwania innego sposobu konstrukcji umowy ubezpieczenia, która byłaby w mniejszym stopniu podatna na wymienione wcześniej problemy. W efekcie zastosowano do ubezpieczeń upraw indeks, który był już wykorzystywany w innych branżach (przede wszystkim energetycznej).

Programy ubezpieczeniowe wykorzystujące ubezpieczenia indeksowe wprowadzono początkowo w Stanach Zjednoczonych i Kanadzie, a indeks dotyczył średniej wielkości plonów lub średniej wielkości dochodu z 1 ha upraw. Nieco później, gdyż pod koniec ubiegłego wieku, do produktów będących mikroubezpieczeniami i skierowanych do krajów rozwijających się zaczęto stosować także inne indeksy, tzw. pogodowe, które dotyczyły przede wszystkim wysokości opadów. W ciagu ostatnich 15 lat zainicjowano kilkadziesiąt programów pilo-

1 W przypadku ubezpieczenia upraw typu multi-risk bądź o charakterze all risk gwarantowanych przez państwo uproszczony wskaźnik szkodowości kształtował się w różnych okresach lat 1970-1980 w USA, Indiach, Brazylii, Kostaryce, Japonii, Meksyku i na Filipinach w granicach od 2,6 do 5,74. J. Skees et al., New approaches to crop yield insurance in developing countries, EPTD Discussion Paper No. 55, International Food Policy Research Institute, Washington 1999, s. 2-3. 
tażowych opartych na ubezpieczeniach indeksowych w krajach rozwijających się, m.in. w Indiach, Chinach, Wietnamie, Meksyku, wielu krajach afrykańskich oraz niektórych krajach europejskich (np. Francja, Hiszpania, Ukraina) ${ }^{2}$. Tylko jednak bardzo nieliczne z nich zostały rozwinięte po fazie pilotażowej na szerszą skalę (najlepszym przykładem są Indie oraz Meksyk), nie spotkały się bowiem z wystarczajacym zainteresowaniem klientów, i to pomimo istotnych zalet dla kupującego (umożliwiających pokrycie zdarzeń dotąd nieubezpieczanych lub ubezpieczanych za bardzo wysoką cenę oraz charakteryzujących się bardzo szybka, przejrzystą likwidacją szkód) ${ }^{3}$. Powstaje zatem bardzo istotne poznawczo i praktycznie pytanie o przyczyny tego stanu rzeczy. Pytanie to jest szczególnie aktualne także dla rynku europejskiego, gdzie w ramach Wspólnej Polityki Rolnej UE określonej na lata 2014-2020 po raz pierwszy zezwolono na dofinansowywanie produktów ubezpieczeniowych opartych na indeksach.

Celem niniejszego artykułu jest identyfikacja czynników determinujących popyt na ubezpieczenia indeksowe w rolnictwie. Zakres przedmiotowy obejmuje zasadniczo indeksy pogodowe, choć uwzględniono uzupełniająco także wyniki badań indeksów dotyczacych średniego plonowania, o ile dotyczyły krajów rozwijajacych się, gdzie ubezpieczenie indeksowe nie ma charakteru przymusowego. Przytoczono ponadto poglądowe dane dotyczace akceptacji takiego rozwiązania w Polsce. Zakres czasowy wyznacza zasadniczo moment wprowadzenia pierwszych prób pilotażowych w zakresie ubezpieczeń indeksowych w krajach rozwijajacych się, a więc 2001 r. ${ }^{4}$, i obejmuje okres do 2015 r.

\section{KONSTRUKCJA UBEZPIECZENIA INDEKSOWEGO}

W ubezpieczeniu indeksowym wypłacane świadczenia nie sa powiązane ze szkodą na poziomie indywidualnym, ale zależą od tego, czy wartość indeksu jest niższa albo wyższa od ustalonego wcześniej poziomu (ang. threshold lub trigger). Indeks to jakiś przyjęty wskaźnik, bazujący np. na wielkości opadów w określonym okresie, prędkości wiatru, poziomie nasłonecznienia, średniej wielkości plonów z 1 ha uprawy mierzonej na określonym (małym) obszarze, poziomie śmiertelności zwierząt itp. Dane służące do obliczenia indeksu moga być zbierane przez stacje meteorologiczne, satelity itd. Indeks powinien być jak najściślej skorelowany z ubezpieczaną potencjalną szkoda, a poziom tego skorelowania wyznacza tzw. ryzyko bazowe. Ryzyko bazowe jest to sytuacja, w której ubezpieczony nie otrzymuje świadczenia, mimo że w rzeczywistości poniósł szkodę, lub otrzymuje świadczenie, mimo że rzeczywiście szkody nie

2 Por. także Agicultural Insurance Schemes, European Commission, s. 49 i 61. Dane dotyczące krajów UE pochodzą z 2006 r., z wyjątkiem Szwecji (2000) i Hiszpanii (2005). Dane dotyczące krajów spoza UE pochodzą (w zależności od państwa) z lat 2000-2006.

${ }_{3}$ Szerzej zob. J. Handschke et al., Koncepcja polis indeksowych i możliwość ich zastosowania w systemie obowiqzkowych dotowanych ubezpieczeń upraw w Polsce, PIU, Warszawa 2015, s. 71.

${ }^{4}$ W 2003 r. wprowadzono pierwszą inicjatywę w życie w Indiach. Szerzej D. Clarke et al., Weather Based Crop Insurance in India (March 1, 2012), World Bank Policy Research Working Paper no. 5985, s. 3. 
poniósł. Im słabiej indeks jest skorelowany z ubezpieczona szkoda, tym jest jej gorszym wyznacznikiem (wyższe jest ryzyko bazowe), co prowadzi do zwiększenia częstotliwości wcześniej wspomnianych sytuacji. Indeks powinien być łatwo weryfikowalny, obiektywny (tzn. niepodatny na manipulację ze strony ubezpieczonego lub ubezpieczającego oraz zakładu ubezpieczeń), mierzony przez organy niezależne od podmiotów stosunku ubezpieczeniowego.

Likwidacja szkód w ubezpieczeniu indeksowym nie wymaga wizyty u rolnika - świadczenie jest wypłacane na podstawie stwierdzenia faktu, że rzeczywista wielkość indeksu (np. skumulowana wielkość opadów) dla danego gospodarstwa jest niższa (np. w przypadku ubezpieczenia od suszy) lub wyższa (np. przy ubezpieczeniu od powodzi) od przyjętego w umowie poziomu. Oznacza to znaczną redukcję kosztów likwidacji szkód i przyspieszenie wypłat, a także zmniejsza skutki asymetrii informacji pomiędzy stronami (utrudniające przykładowo ustalenie stopnia współprzyczynienia się do powstania szkody). Zamiast likwidować kilkadziesiąt szkód na terenie np. danej gminy, wystarczy znać rzeczywisty poziom indeksu dla tego obszaru i porównać go z przyjętym wcześniej triggerem. Większość produktów ubezpieczeń indeksowych w krajach rozwijajacych się ma prostą konstrukcję, tj. występuje tylko jeden poziom triggera i jeden poziom świadczenia ${ }^{5}$. Wykorzystywane w tych produktach indeksy opierają się najczęściej na wskaźnikach opadów i dotyczą strat wywołanych konkretnym zdarzeniem, tj. suszą lub nadmiernymi opadami. Zdecydowanie rzadziej spotykane sa produkty o indeksach dotyczących całkowitego spadku plonów, bez względu na przyczyny, które ten spadek wywołały.

\section{POPYT NA UBEZPIECZENIE INDEKSOWE - WYNIKI BADAŃ ZAGRANICZNYCH}

\section{Czynniki związane z produktem}

\subsection{Ryzyko bazowe}

W ramach konstrukcji produktu kluczowe wydaje się kilka elementów: indeks, który decyduje o poziomie tzw. ryzyka bazowego, ilość i poziom triggerów, wysokość świadczenia lub świadczeń (jeśli ich poziom jest zróżnicowany), czas trwania umowy oraz cena za sam produkt.

Konsekwencją tzw. ryzyka bazowego w ubezpieczeniu indeksowym może być sytuacja, w której rolnik ponosi szkodę, ale nie otrzymuje świadczenia. Im wyższe jest ryzyko bazowe, tym takich przypadków może być więcej. Skutkiem jest nadwyrężenie zasady realności ochrony ubezpieczeniowej, która jest zasadą bezwzględną dla realizacji podstawowej funkcji ubezpieczeń - ochrony

\footnotetext{
${ }^{5}$ Wyjątek stanowi np. S. Cole et al., Barriers to household risk management: evidence from India, „American Economic Journal: Applied Economics” 5(1), 2013, s. 104-135; X. Giné, D. Yang, Insurance, credit, and technology adoption: field experimental evidence from Malawi, „Journal of Development Economics" 89(1), 2009, s. 1-11; D. Stein, Paying premiums with the insurers money: insurance decisions in a repeated interaction, niepublikowane.
} 
ubezpieczeniowej. Oczekiwana konsekwencją takiego stanu rzeczy jest zmniejszenie popytu na tego typu produkt. Zmniejszenie popytu w przypadku wysokiego ryzyka bazowego może ponadto wynikać z awersji do niejasności (ang. ambiguity aversion), kiedy podmiot, ze względu na to, że nie preferuje sytuacji niepewności, mając wątpliwości co do stopnia korelacji pomiędzy wartością indeksu a ponoszonymi stratami, ogranicza transakcje kupna ubezpieczenia ${ }^{6}$.

Tak zwane ryzyko bazowe można zmierzyć i nadać mu charakter obiektywny (jest to zreszta niezbędne przy podejmowaniu decyzji dotyczącej konstrukcji produktu). Pytaniem zasadniczym jest jednak to, jak potencjalny kupujacy postrzega ryzyko bazowe, czyli jaka jest jego subiektywna ocena w zakresie możliwych skutków oraz prawdopodobieństwa ich realizacji. Ujęcie obiektywne i subiektywne może znaczaco się różnić, co wynika z procesu postrzegania ryzyka oraz czynników, które na ten proces wpływaja?

Dostępne wyniki badań nie potwierdzają istotnego znaczenia dla popytu takich czynników, jak: odległość gospodarstwa do najbliższej stacji mierzącej opady, różnica w zakresie wysokości nad poziomem morza pomiędzy stacja a gospodarstwem, odległość do centrum (centrum najbliższej najmniejszej jednostki administracyjnej), odległość pomiędzy domem a polem czy deklarowanie innych niż średnie dla danego obszaru administracyjnego opady. Jedynie różnica w zakresie wysokości nad poziomem morza pomiędzy centrum a gospodarstwem okazała się istotna statystycznie i zmniejszała w niewielkim stopniu poziom popytu8.

Jak wspomniano wcześniej, poziom ryzyka bazowego zależy od rodzaju wybranego indeksu, tj. czy zostanie on zbudowany na wskaźnikach mierzacych tylko wielkość opadów, wskaźnikach uzyskiwanych z obserwacji satelitarnych itd. Okazuje się, że wybór indeksu ma wpływ na akceptację i decyzję o zakupie ${ }^{9}$.

Rajiv Seth, Valeed A. Ansari i Manipadma Datta na podstawie przeprowadzonych badań stwierdzili, że zauważyć można preferencję respondentów w odniesieniu do kombinacji wskaźników opadów i temperatury względem indeksu opartego tylko na wskaźniku opadów ${ }^{10}$, który notabene jest dominujący w produktach indeksowych dla rolników.

${ }^{6}$ G. Bryan, Ambiguity and insurance, niepublikowane za: C. McIntosh et al., Productivity, credit, risk, and the demand for weather index insurance in smallholder agriculture in Ethiopia, „Agricultural Economics” 44(4-5), 2013, s. 400. Zob. także M. Carter et al., Index-based weather insurance for developing countries: a review of evidence and a set of propositions for up-scaling, Background document for the workshop: „Microfinance products for weather risk management in developing countries: State of the arts and perspectives", Paris, June 25 2014, s. 13.

7 Szeroko na ten temat Rück, Bayerische (1993), Risiko ist ein Konstrukt. Wahrnehmungen zur Risikowahrnehmung, München 1993.

8 Zob. C. McIntosh et al., op. cit., s. 413.

9 Tak L. Vandeveer, Demand for area crop insurance among litchi producers in northern Vietnam, „Agricultural Economics” 26, 2001, s. 183, choć mamy tu do czynienia z indeksem plonowania, a nie pogodowym.

${ }^{10}$ R. Seth et al., Weather-risk hedging by farmers: an empirical study of willingness-to-pay in Rajasthan, India, „The Journal of Risk Finance” 10(1), 2009, s. 61. Badany produkt nie był ubezpieczeniem indeksowym, ale derywatem pogodowym. 


\subsection{Konstrukcja produktu}

Nie bez znaczenia dla wysokości popytu na produkty indeksowe dla rolników pozostają poziom wyznaczonych triggerów oraz wysokość świadczeń. Nancy McCarthy przeprowadziła badania w Maroku, oferując w każdym z czterech badanych regionów sześć hipotetycznych produktów (trzy różne poziomy triggerów oraz dwa różne poziomy świadczeń) ${ }^{11}$. Wyniki wskazuja, że w regionach o większym zróżnicowaniu opadów rolnicy preferowali kontrakty o wyższym poziomie triggerów (skutkujące częstszymi wypłatami) oraz tańsze, tj. oferujące niższy poziom świadczeń. Podobne wyniki uzyskał w zakresie triggerów Alexander Sarris wraz ze swoim zespołem w Tanzanii ${ }^{12}$.

Z dostępnych badań wynika, że popyt na ubezpieczenie indeksowe istotnie zależy od ceny za ubezpieczenie i jest to (jak można było oczekiwać) korelacja ujemna, choć jej wielkość jest w poszczególnych badaniach różna ${ }^{13}$. Wprowadzenie dopłat do ceny, nawet o relatywnie niewielkiej wysokości, istotnie zwiększa popyt i jest to silniejszy bodziec dynamizujący aniżeli inne czynniki, np. cechy demograficzne rolnika, charakterystyki jego gospodarstwa, doświadczenia $\mathrm{z}$ przeszłości czy inne determinanty behawioralne ${ }^{14}$. Warto tu zauważyć, że proponowane ubezpieczenia indeksowe cechuje niski udział wartości świadczenia względem składki (ang. payout-to-premia ratio). Shawn Cole z zespołem, przeprowadzajac swoje badania w Indiach, gdzie od czterech lat funkcjonował pierwszy na świecie program ubezpieczeń indeksowych, stwierdzili, że wspomniany wskaźnik oscylował na poziomie od 33-55\% ('́rednio 46\%) i był znacząco niszy od wskaźników popularnych ubezpieczeń w krajach wysoko rozwiniętych ${ }^{15}$. Tak wysokie ceny za ubezpieczenia indeksowe wynikały z wysokich kosztów administracyjnych, niskiej wartości pojedynczych kontraktów w porównaniu z kosztami operacyjnymi oraz braków w danych niezbędnych do zaprojektowania i prowadzenia ubezpieczenia ${ }^{16}$. Biorac pod uwagę oszacowaną dla badanej grupy elastyczność popytu, podwyższenie wskaźnika świadczenia-do-ceny do poziomu średniego

11 Szerzej zobacz N. A. McCarthy, Demand for rainfall-index based insurance: a case study from Morocco, Intl Food Policy Res Inst., EPTD Discussion Paper No. 106, 2003.

12 A. Sarris et al., Producer demand and welfare benefits of rainfall insurance in Tanzania, Rome: FAO Commodities and Trade Policy Research Working Paper Series, 18, 2006, s. 15.

${ }_{13}$ Tak S. Cole et al., op. cit., s. 120 i 123, gdzie redukcja ceny o 10\% powoduje wzrost popytu od 10,4 do 11,6\%; L. Vandeveer, op. cit., s. 181, gdzie 10-procentowa redukcja ceny dla ubezpieczenia indywidualnego zwiększała popyt o $6,8 \%$, a dla ubezpieczenia dla całej gminy tylko o $2,2 \%$. Pierwsze badanie dotyczyło jednak rzeczywistego, a drugie hipotetycznego (deklarowanego) popytu. A. Seth, wyznaczając w ramach eksperymentu cenę za hipotetyczne derywaty pogodowe, również stwierdził bardzo istotną korelację pomiędzy wielkością akceptowanej przez respondentów ceny a deklarowanym popytem (A. Seth, op. cit., s. 60).

${ }_{14}$ C. McIntosh, op. cit., s. 413.

15 Przykładowo przeciętna wartość tego wskaźnika dla indywidualnych ubezpieczeń komunikacyjnych i mieszkaniowych w USA wynosi 65-76\%. Szerzej S. Cole et al., op. cit., s. 108 i 123.

${ }^{16}$ X. Giné, Making Index Insurance Work for the Poor, Presentation taken during the Policy Research Talk on April 7, 2015, The World Bank. 
w USA spowodowałby, ceteris paribus, wzrost popytu od $36 \%$ do $66 \%$ (w zależności od produktu) ${ }^{17}$.

Z dostępnych badań wynika także, że dłuższy czas trwania umowy zwiększa prawdopodobieństwo zakupu ubezpieczenia indeksowego, a rolnicy przedkładali zakup produktów indeksowych w grupach nad zawarcie indywidualnej umowy ${ }^{18}$. Z kolei oferowanie produktów wiązanych z kredytem (na finansowanie nakładów związanych z prowadzeniem uprawy lub składki) nie musi prowadzić do zwiększenia popytu ${ }^{19}$.

\section{Czynniki związane z ubezpieczonym}

\subsection{Posiadane aktywa, dochody i ograniczenia w zakresie płynności}

Wyniki badań dotyczących wpływu sytuacji majątkowej, tj. posiadanych aktywów na popyt na ubezpieczenia indeksowe, nie są jednoznaczne. Najwyższe korelacje w tym zakresie zaobserwować można w odniesieniu do wartości zwierząt hodowlanych, choć ich kierunek jest zmienny ${ }^{20}$. Znaczenie pozostałych aktywów jest niewielkie, choć istotne statystycznie ${ }^{21}$.

Wydaje się, że ważkie znaczenie w kontekście zakupu ubezpieczeń powinien odgrywać dochód gospodarstwa domowego. Wyniki badań w większości potwierdzają korelację dodatnia, jest ona jednak słaba ${ }^{22}$. Wyjaśnień tej dość zaskakującej prawidłowości mogą dostarczyć rozważania na temat płynności finansowej gospodarstw. Okazuje się bowiem, że to nie zasoby gospodarstwa czy poziom jego dochodów, ale ich rozkład w ciagu roku i możliwość dysponowania odpowiednimi środkami w momencie zapadalności zapłaty składki odgrywają zasadniczą rolę w kontekście podejmowania decyzji o zakupie

17 S. Cole et al., op. cit., s. 123.

18 R. A. Seth, op. cit., s. 61.

19 Choć w badaniach popytu hipotetycznego jest czynnikiem wpływającym dodatnio. Zob. porównanie C. McIntosh et al., op. cit., s. 407 oraz 411.

${ }^{20}$ R. Seth, op. cit., s. 61, stwierdził korelacje pozytywna, a S. Chantarat et al. - negatywna (eidem, Willingness to pay for index based livestock insurance: results from a field experiment in northern Kenya, Working Papers 2009, s. 29). Zaznaczyć należy, że badane były inne produkty: w pierwszym przypadku derywat pogodowy, w drugim - ubezpieczenie indeksowe dla zwierząt.

21 Por. S. Chantarat et al., op. cit., s. 29, przy czym posiadanie aktywów tzw. produkcyjnych (zwierzęta niewypasane lokalnie, sklepy, działki w mieście itd.) jest pozytywnie skorelowane, natomiast pozostałych aktywów negatywnie skorelowane z popytem. Inne zob. S. Cole et al., op. cit., s. 127 (zasoby mierzone indeksem), X. Giné et al., Patterns of rainfall insurance participation in rural India, „World Bank Economic Review” 22(3), 2008, s. 539-566 (s. 556 dotyczy wartości majątku i dzierżawionej ziemi); C. Turvey, R. Kong, Farmers' Willingness to Purchase Weather Insurance in Rural China, SSRN Working Paper Series 2010, s. 19.

${ }^{22}$ Zob. np. L. Vandeveer, op. cit., s. 181; A. Sarris et al., op. cit., s. 26; X. Giné, D. Yang, op. cit., s. 9; S. Cole et al., op. cit., s. 127. Jedynie u S. Chantarat et al., op. cit., s. 29, poziom korelacji był zdecydowanie wyższy (0,45 przy poziomie istotności 10\%). Z kolei McIntosh et al. zidentyfikowali bardzo słabą korelację ujemną (C. McIntosh et al., op. cit., s. 413). 
ubezpieczenia ${ }^{23}$, a dopasowanie płatności składek do płynności gospodarstw może podnieść popyt o $34 \%{ }^{24}$. Przypuszczenia te potwierdza także negatywna korelacja pomiędzy dostępem do kredytu a nabywaniem ubezpieczeń ${ }^{25}$.

\subsection{Historia szkodowości i stosowane metody kontroli ryzyka}

Doświadczenia w zakresie szkód z przeszłości maja przełożenie na postrzeganie ryzyka ${ }^{26}$. Postrzeganie ryzyka z kolei wpływa na podejmowane działania w ramach zarządzania tym ryzykiem i ewentualny zakup ubezpieczenia ${ }^{27}$. Istotnym pytaniem jest to, czy prawidłowość tę możemy także zaobserwować w przypadku ubezpieczeń indeksowych, tj. czy rzeczywiście odniesione szkody w przeszłości zwiększają prawdopodobieństwo zakupu ubezpieczenia indeksowego w kolejnym okresie, oraz jak inne podejmowane działania kontrolne (prewencyjne, represyjne) modyfikuja popyt na ubezpieczenie indeksowe.

Wyniki badań przeprowadzonych w odniesieniu do rzeczywistego popytu na ubezpieczenie indeksowe od suszy w stanie Andhra Pradesh w Indiach nie pozwalają na stwierdzenie, że samo tylko doświadczenie szkód w przeszłości prowadzi do zwiększenia popytu na ubezpieczenie indeksowe. Wykluczono autokorelację pomiędzy zdarzeniami, która pozwoliłaby przypuszczać rolnikowi (jeśli byłby jej świadomy), że skoro doznał szkody w bieżącym okresie, to bardziej prawdopodobna jest szkoda w kolejnym okresie. Stwierdzono, że zmienność w zakresie opadów deszczu oraz średnia wielkość opadów nieznacznie (jeśli w ogóle były istotne statystycznie) wpływały na zakup ubezpieczenia indeksowego, zatem nie można wyciagnąć jednoznacznego wniosku, że szkoda doznana w poprzednim okresie zmniejsza płynność finansową i w ten sposób ogranicza możliwość nabycia ubezpieczenia w okresie kolejnym lub że doznanie szkody w roku poprzednim zwiększa subiektywną ocenę prawdopodobieństwa wystapienia tego samego zdarzenia w okresie następnym ${ }^{28}$. Inne badania dotyczace zmienności „ubezpieczanych” wartości, tj. zmienności plonowania lub dochodu - wskazują na dodatni, choć niewielki wpływ na popyt na ubez-

${ }^{23}$ A. Sarris et al., op. cit., s. 26; A. Patt et al., Making index insurance attractive to farmers, „Mitigation and Adaptation Strategies for Global Change” 14(8), 2009, s. 749.

${ }^{24}$ Szacunki dla stanu Andhra Pradesh w Indiach - X. Giné, op. cit., passim.

25 C. McIntosh et al., op. cit., s. 413.

${ }^{26}$ P. Slovic et al., Risk as analysis and risk as feelings: some thoughts about affect, reason, risk and rationality, „Risk Analysis” 24, 2004, s. 311-322; M. C. Ho et al., How do disaster characteristics influence risk perception?, „Risk Analysis” 28, 2008, s. 635-643; D. Västfjäll, The affect heuristic, mortality salience, and risk: domain-specific effects of a natural disaster on risk-benefit perception, „Scandinavian Journal of Psychology” 55, 2014, s. 527-532.

${ }_{27}$ D. J. Beal, Emerging issues in risk management in farm firms, ,Review of Marketing and Agricultural Economics” 64(3), 1996, s. 336-347; R. Ullah et al., Factors effecting farmers' risk attitude and risk perceptions: the case of Khyber Pakhtunkhwa, Pakistan, „International Journal of Disaster Risk Reduction” 13, 2015, s. 151-157.

${ }_{28}$ Szerzej zob. D. Stein, op. cit, s. 20-24. Podobnie Sarris et al. zauważyli dodatni związek pomiędzy skłonnością do zapłaty (WTP) a ilością lat w ciagu ostatnich 10 lat, w których nastapił znaczący spadek dochodu gospodarstwa poniżej poziomu normalnego oraz pomiędzy WTP a wystąpieniem od 1998 r. suszy wpływającej na warunki życiowe, jednakże obie wartości były nieistotne statystycznie w modelu (przy przyjętym poziomie istotności 10\%). A. Sarris et al., op. cit., s. 26. 
pieczenie indeksowe (dotyczy to zarówno zmienności obiektywnej liczonej na podstawie danych, jak i subiektywnej percepcji tej zmienności czy oczekiwanej wielkości straty ${ }^{29}$.

Stosowanie kontroli fizycznej i finansowej w ramach zarządzania ryzykiem może, choć nie musi modyfikować popyt na ubezpieczenia indeksowe. Wyniki badań wskazuja, że nieistotne jest stosowanie nawadniania, zarówno w aspekcie popytu hipotetycznego, jak i rzeczywistego ${ }^{30}$. Pozytywny wpływ na decyzję o zakupie ubezpieczenia ma z kolei poziom stosowania chemicznych nawozów sztucznych $^{31}$. Ponadto, jak można było przypuszczać, korzystanie z pomocy finansowej rodziny $\mathrm{w}$ przypadku wystapienia szkody wpływa negatywnie na hipotetyczny popyt na ubezpieczenia ${ }^{32}$.

\subsection{Otrzymane wcześniej odszkodowania i świadczenia}

Bazując na danych 3-letnich w zakresie funkcjonowania ubezpieczeń indeksowych w Indiach sprzedawanych przez BASIX ${ }^{33}$, Dan Stein wykazał, że otrzymanie przez rolnika świadczenia z ubezpieczenia indeksowego zwiększa prawdopodobieństwo nabycia przez niego tego ubezpieczenia w okresie następnym o średnio $10-20 \%^{34}$. Wzrost ten jest silnie zróżnicowany i zależy od wysokości otrzymanego świadczenia.

Zatem otrzymanie świadczenia w wysokości co najmniej dwukrotnej wartości opłaconej składki powoduje zwiększenie prawdopodobieństwa ponownego zakupu o 2,5 do 3 razy. Otrzymanie świadczenia wyższego niż składka, ale mniejszego niż jej dwukrotność wywołuje efekt pozytywny, lecz w granicach błędu statystycznego. Z kolei otrzymanie niższego świadczenia od składki powoduje niewielki spadek prawdopodobieństwa ponownego zakupu ${ }^{35}$. Zaobserwowana prawidłowość można wyjaśnić, opierając się na modelu awersji do straty (ang. model of loss aversion) - płacona w kolejnym okresie składka traktowana jest jako zmniejszenie otrzymanej wcześniej korzyści (o ile świadczenie jest wyższe niż składka), a nie jako rzeczywista strata. Tym samym zgodnie z założeniami modelu jej płatność jest mniej dotkliwa niż rzeczywista strata, co czyni ubezpieczenie bardziej atrakcyjnym ${ }^{36}$. Ze względu na to, że wśród osób, które dokonują ponownego zakupu ubezpieczenia indeksowego, sa także takie, względem których nie stosowano działań marketingowych, przy-

${ }^{29}$ C. Turvey, R. Kong, op. cit., s. 20; R. Seth, op. cit., s. 61; S. Chantarat et al., op. cit., s. 29. W tym ostatnim przypadku warto dodać, że istotna statystycznie w modelu okazała się oczekiwana wielkość straty w kolejnym roku, a nie rzeczywisty udział lat, w których gospodarstwo poniosło straty powyżej 200\% średniej wielkości strat w ciagu ostatnich 11 lat.

${ }^{30}$ C. Turvey, R. Kong, op. cit., s. 20; A. Sarris et al., op. cit., s. 26; S. Cole et al., op. cit., s. 127.

31 C. McIntosh et al., op. cit., s. 413.

32 A. Sarris et al., op. cit., s. 26.

${ }^{33}$ BAXIS została utworzona w 1996 r. i jest nazwą grupy przedsiębiorstw, których celem jest udzielanie wsparcia gospodarstwom domowym w celu osiągnięcia przez nie możliwości samoutrzymania. W 2005 r. wcześniejszy projekt pilotażowy w zakresie mikroubezpieczeń indeksowych dla rolników został rozszerzony i obją sześć stanów.

${ }^{34}$ D. Stein, op. cit., s. 8.

35 Ibidem, s. 19.

36 Szerzej ibidem, s. 12-19. 
puszcza się, że ponowny zakup po otrzymaniu świadczenia może być spowodowany tzw. efektem potwierdzenia (ang. confirmation bias). Otrzymane świadczenie utwierdza takie osoby w przekonaniu o tym, że podjęta decyzja co do zawarcia ubezpieczenia była słuszna i skłania do ponownego zakupu ${ }^{37}$. Bardzo istotny wpływ otrzymanych świadczeń na zakup ubezpieczenia indeksowego w kolejnych okresach potwierdziło także kolejne badanie rzeczywistego popytu na ubezpieczenia indeksowe w Indiach. Wypłata świadczeń w danej wiosce istotnie zwiększała prawdopodobieństwo zakupu w kolejnym roku i dotyczyła nie tylko osób, które rzeczywiście otrzymały świadczenia (tu wzrost prawdopodobieństwa zakupu o ok. 50\%), ale także osób mieszkajacych we wioskach, w których świadczenia były wypłacane (wzrost prawdopodobieństwa zakupu o $25 \%)^{38}$. Efekt ten był długotrwały, ale zmniejszający się w kolejnych trzech latach. W przypadku bezpośrednich beneficjentów świadczeń najsilniej oddziaływał w drugim i trzecim roku po otrzymaniu zapłaty, natomiast w odniesieniu do pozostałych osób w kolejnym sezonie ${ }^{39}$. Znaczenie otrzymywanych świadczeń potwierdzają też inne badania ${ }^{40}$.

\subsection{Zaufanie do instytucji i produktu}

Przeglądając wyniki badań, można stwierdzić, że w ramach szeroko pojmowanego czynnika „zaufanie” rozważane są dwa aspekty, tj. zaufanie do instytucji zaangażowanej $\mathrm{w}$ program ubezpieczeniowy (ang. trust in the third party) oraz zaufanie względem samego produktu ubezpieczenia indeksowego.

Prawdopodobieństwo zakupu ubezpieczenia rośnie, gdy rolnik miał wcześniejszy kontakt z daną instytucją (bankiem, zakładem ubezpieczeń, organizacją prowadząca program, pośrednikiem), tj. był lub jest obecnie jej klientem (w zakresie także produktów nieubezpieczeniowych), należy do jakiegoś stowarzyszenia przez nią prowadzonego lub pośrednik finansowy, z którym ma kontakt, jest polecony przez daną instytucję ${ }^{41}$. W zależności od badań (sposobu ich przeprowadzenia, okoliczności itd.) zaufanie do instytucji oferujacej ubezpieczenie indeksowe (mierzone w różnoraki sposób) zwiększa popyt na ubezpieczenie indeksowe od 0,1 do 8 razy $^{42}$.

Zaufanie względem produktu, tj. przekonanie, że produkt jest wiarygodny i rolnik otrzyma świadczenie na umówionych warunkach ${ }^{43}$, stanowi kolej-

${ }^{37}$ S. Cole et al., Dynamics of demand for index insurance: evidence from a long-run field experiment, „American Economic Review” 104(5), 2014, i przytoczone wyniki analizy statystycznej.

38 Ibidem.

39 Ibidem.

${ }^{40}$ Zob. np. H. Cai et al., Microinsurance, trust and economic development: evidence from a randomized natural field experiment, NBER working paper 15396, s. 23; H. Cai et al., The effect of microinsurance on economic activities: evidence from a randomized field experiment, "The Review of Economics and Statistics" 97(2), 2015, s. 298.

${ }^{41}$ X. Giné et al., Patterns..., s. 558; A. Patt, op. cit., s. 746; S. Cole et al., op. cit., s. 124. Z kolei brak lub niewielki wpływ zauważyli w swoim badaniu C. McIntosh et al., op. cit., s. 413.

${ }^{42}$ X. Giné et al., Patterns..., s. 558; S. Cole et al., op. cit., s. 124.

${ }_{43} \mathrm{~W}$ literaturze znane jako zasada realności (J. Handschke, Funkcje i zasady ubezpieczeń gospodarczych, w: T. Sangowski (red.), Ubezpieczenia gospodarcze, Poltext, Warszawa 1998, s. 83-85). 
ny istotny czynnik zwiększający popyt na ubezpieczenie indeksowe ${ }^{44}$. Część autorów wskazuje tu na kluczowe znaczenie otrzymywanych wcześniej przez rolników lub osoby z ich najbliższego otoczenia świadczeń lub odszkodowań ${ }^{45}$. Ze względu na to, że prawdopodobieństwo zakupu ubezpieczenia rośnie (i to znacznie) nie tylko w odniesieniu do osób, które otrzymały świadczenia, ale także tych, które były tego świadkami (mieszkające w tej samej wiosce), przypuszczalnie mówić można o efekcie „rozpowszechnienia się wiedzy”, która prowadzi do zwiększenia zaufania do produktu ${ }^{46}$.

\subsection{Wiedza finansowa}

Można przypuszczać, że większa wiedza finansowa rolnika zwiększa szansę na zakup przez niego produktu, który rozumie i który odpowiada jego potrzebom. Tym samym ewentualne rozczarowanie związane $\mathrm{z}$ ubezpieczeniem jest mniej prawdopodobne. Z badań wynika, że rzeczywiście poziom wiedzy finansowej jest pozytywnie skorelowany z zakupem ubezpieczenia indeksowego, przy czym szczególnie istotne okazuje się rozumienie pojęcia prawdopodobieństwa oraz konstrukcji konkretnego produktu ubezpieczeniowego ${ }^{47}$. Pewnym wyznacznikiem wiedzy finansowej może też być posiadanie innego ubezpieczenia, choć wyniki badań w zakresie jego wpływu na popyt na ubezpieczenie indeksowe nie są jednoznaczne ${ }^{48}$. Wiedzę finansową można próbować podnosić przez różne działania o charakterze edukacyjnym i w ten sposób stymulować popyt. Z przeprowadzonych eksperymentów wynika, że jest to skuteczne ${ }^{49}$. Warto tu zauważyć, że zaufanie i wiedza (finansowa) moga być względem siebie substytucyjne.

\subsection{Awersja do ryzyka i inne cechy demograficzne i behawioralne}

Awersję do ryzyka i jej wpływ na popyt na ubezpieczenie indeksowe badano wielokrotnie. Wydaje się to tym bardziej istotne, że z założenia traktuje się rolników jako grupę o niskiej skłonności do ryzyka. Tym bardziej zatem zaskakują wyniki badań: powiązania pomiędzy awersją do ryzyka a popytem na ubezpieczenia indeksowe (rzeczywistym lub hipotetycznym) okazywały się

\footnotetext{
${ }^{44}$ H. Cai et al., Microinsurance..., s. 23; A. Patt, op. cit., s. 750; H. Cai et al., The effect..., s. 292 i 298.

45 Kwestia ta została omówiona wcześniej.

${ }^{46}$ D. Stein we wcześniejszych badaniach był skłonny do odrzucenia takiej hipotezy. Por. D. Stein, op. cit., s. 28.

47 S. Cole et al., Barriers..., s. 127; R. Seth et al., op. cit., s. 61 ,

${ }_{48}$ Według Cole et al. posiadanie innej umowy ubezpieczenia zwiększało prawdopodobieństwo zakupu ubezpieczenia indeksowego o ok. 11\% (Barriers..., s. 127), z kolei Giné et al. ustalili, że zależność ta, choć dodatnia, okazała się nieistotna statystycznie (X. Giné, Patterns..., s. 556). Warto dodać, że posiadanie konta bankowego, choć jest skorelowane dodatnio z potencjalnym popytem, także nie okazało się zmienną istotną statystycznie (S. Chantarat et al., op. cit., s. 29).

${ }^{49}$ S. Gaurav et al., Marketing complex financial products in emerging markets: evidence from rainfall insurance in India, „Journal of Marketing Research” 48, 2011, November; X. Giné et al., Social networks, financial literacy and index insurance, Enhancing financial capability and behavior in low-and middle-income countries, (2011), s. 195.
} 
negatywne, choć często statystycznie nieistotne ${ }^{50}$. Ten zaskakujący kierunek wpływu tłumaczyć można tym, że prawdopodobnie sam produkt był oceniany jako „ryzykowny” albo z powodu postrzeganego ryzyka bazowego, albo na skutek niezrozumienia konstrukcji i działania produktu.

Cechy demograficzne, takie jak: wiek rolnika, jego wykształcenie ogólne, cechy osobowościowe (skłonność do wyolbrzymiania rzeczywistości, ufność, umiejętność kalkulacji, cierpliwość, wyznawana religia), nie sa istotne w kontekście popytu na ubezpieczenia indeksowe ${ }^{51}$, choć ograniczenie uwagi poświęconej rolnikowi podczas procesu sprzedaży (brak wizyty) lub rodzaj akcentowanych w materiałach informacyjnych korzyści (czy w kontekście indywidualnym czy grupowym) oraz umieszczanie w ulotkach symboli religijnych innych wyznań już tak ${ }^{52}$.

\section{STOSUNEK POLSKICH ROLNIKÓW DO PRODUKTU INDEKSOWEGO}

Ubezpieczenia indeksowe nigdy nie były obecne w Polsce, trudno zatem wyrokować na temat akceptacji samej idei i ewentualnej gotowości do zakupu. Dotychczas przeprowadzono tylko jedną próbę empirycznej oceny akceptacji tego typu rozwiązań w rolnictwie i dotyczyła ona ubezpieczenia indeksowego od suszy ${ }^{53}$.

Okazało się, że poziom akceptacji rozwiązania indeksowego jest stosunkowo wysoki (57\% respondentów oceniło, że koncept się podoba) ${ }^{54}$. Był on

${ }^{50}$ Wyniki istotne statystycznie uzyskano w S. Cole et al., Barriers..., s. 124.

51 C. McIntosh et al., op. cit., s. 413; S. Cole et al., op. cit., s. 121-122.

52 Szerzej S. Cole et al., op. cit., s. 121-123 i 126.

${ }^{53}$ Badanie przeprowadzone zostało w marcu 2012 r. metodą CATI przy wykorzystaniu kwestionariusza ankiety. Badaniem objęte zostały gospodarstwa rolne w Polsce o powierzchni powyżej 1 ha, znajdujace się poza powiatem miastem, zgodnie ze spisem rolnym z 2002 r., oraz na terenach suszowych. Łączna próba wyniosła 5000 wywiadów i dobrana została w ten sposób, by wyniki były reprezentatywne dla Polski ze względu na dwa kryteria, tj. wielkość gospodarstwa oraz położenie gospodarstwa. Rolnikom przedstawiono następujący koncept: „Istnieje możliwość wprowadzenia w Polsce nowego ubezpieczenia w zakresie ubezpieczenia upraw od suszy, pozwalającego na przetrwanie jej skutków przez rolników. Na większości obszarów rolnych w Polsce występują czasowe niedobory wody, które mogą znacznie obniżyć plonowanie. Na rynku dostępne jest ubezpieczenie upraw od suszy, ale jest ono dla rolników za drogie, a likwidacja szkód kłopotliwa. Nowy pomysł to ubezpieczenie indeksowe suszy. W celu oszacowania wielkości ubytku w plonie nie jest konieczna wizyta towarzystwa ubezpieczeniowego na Pana/Pani polu. Ubytek jest szacowany odgórnie przez niezależny Instytut Upraw i Nawożenia Gleb w Puławach, który monitoruje suszę w Polsce. Jeśli ten Instytut stwierdzi, że plonowanie danej uprawy na danej klasie gleby w danej gminie jest mniejsze niż 50\% średniego plonu z ostatnich lat, to każdemu rolnikowi, który zdecyduje się na ubezpieczenie, będzie wypłacona określona kwota. Wypłata ryczałtowa przekazywana przez towarzystwo ubezpieczeniowe będzie taka sama dla rolników z danej gminy i będzie dostosowana do rodzaju uprawy i klasy gleby. Wypłacona kwota raczej nie pokryje w pełni straty, ale pozwoli rolnikowi na rozpoczęcie produkcji w kolejnym okresie wegetacji. Ubezpieczenie indeksowe pozwala na przetrwanie w przypadku suszy". Szerzej zob. J. Handschke et al., op. cit., s. 7-22.

${ }_{54}$ Te i dalsze wyniki sa cytowane za: M. Kaczała, D. Wiśniewska, Factors influencing farmers' decisions on drought index insurance in Poland, The Third World Risk and Insurance Economics Congress (WRIEC) 2015, Monachium, 2-6 sierpnia 2015. 
istotnie statystycznie ${ }^{55}$ skorelowany z lokalizacją gospodarstwa, dominujacca klasa ziemi oraz poziomem wykształcenia osoby prowadzącej gospodarstwo. Pozostałe cechy charakteryzujące gospodarstwo lub rolnika, takie jak wiek, płeć, wielkość gospodarstwa, przeznaczenie produkcji (na potrzeby własne lub na rynek), czy dominujący rodzaj produkcji okazały się nieistotne statystycznie. Podobnie na ocenę konceptu ubezpieczenia indeksowego istotnie nie wpływały: wielkość przeciętna dochodu gospodarstwa, udział dochodów z działalności rolniczej w łącznych dochodach czy sezonowość dochodów. Poziom akceptacji konceptu nie zależał także, co może zaskakiwać, od doświadczeń związanych z suszą (częstotliwość i dotkliwość suszy w ostatnich 10 latach), ani też od subiektywnej oceny zagrożenia, jakie susza stwarza dla funkcjonowania całości gospodarstwa. Istotne znaczenie miał jednak fakt finansowania z ubezpieczeń (jakichkolwiek) szkód w uprawach oraz posiadanie umowy tradycyjnego ubezpieczenia upraw w roku poprzedzajacym badanie, w tym w szczególności ubezpieczenia od suszy. Z kolei najsilniejszym korelatem akceptacji nowych rozwiąań okazały się opinie na temat ubezpieczeń, w tym przekonanie o tym, że ubezpieczenie jest zabezpieczeniem bytu rodziny, gwarantuje wysokie odszkodowania oraz że ceny tradycyjnych ubezpieczeń rolnych są zbyt wysokie. Można zatem stwierdzić, że akceptacja nowego rozwiązania ubezpieczeniowego zależała przede wszystkim od czynników pozaekonomicznych, a zasadniczą rolę odgrywają stosunek do ubezpieczeń w ogóle i wcześniejsze korzystanie z ubezpieczenia upraw łącznie z doświadczeniem otrzymania odszkodowania.

Z kolei gotowość do zakupu ubezpieczenia indeksowego przy zaproponowanej cenie i wysokości świadczenia (popyt hipotetyczny) zadeklarowało $14 \%$ badanych, $45 \%$ było niezdecydowanych, natomiast $41 \%$ stwierdziło, że produktu takiego nie kupi. Najbardziej istotnym ${ }^{56}$ czynnikiem wpływającym na pozytywną decyzję był poziom akceptacji samej koncepcji indeksu, lokalizacja gospodarstwa, opinie na temat ubezpieczeń oraz częstotliwość suszy w przeszłości. Nieistotny w kontekście deklarowanego zakupu był dochód gospodarstwa rolnego. Zastanawiajacy jest fakt, że wśród osób, które akceptują sam pomysł ubezpieczenia indeksowego, zdecydowana większość nie zdecydowałaby się na jego zakup lub waha się w kwestii zakupu. Okazuje się, że wpływające na ostateczną decyzję są w tym przypadku następujące czynniki: częstotliwość pokrywania szkód w uprawach z ubezpieczenia w ciagu ostatnich 10 lat, poziom akceptacji opinii, że każdy rolnik powinien się ubezpieczać oraz że ubezpieczenie zapewnia poczucie bezpieczeństwa, a także lokalizacja na terenie województwa dolnoślaskiego. Można ponadto stwierdzić, że w zależności od rodzaju uprawy istnieją wyraźne preferencje rolników co do wysokości triggerów i świadczeń oraz ceny ${ }^{57}$.

\footnotetext{
55 Przy poziomie istotności 10\%.

56 Przy poziomie istotności 5\%.

${ }^{57}$ Szerzej zob. J. Handschke et al., op. cit., s. 156-161.
} 


\section{PODSUMOWANIE}

Rozważania dotyczące czynników wpływających na kształtowanie potencjalnego popytu na ubezpieczenia indeksowe muszą uwzględniać fakt, że część badań dotyczy popytu na hipotetyczny produkt, część natomiast popytu na produkt, który rzeczywiście funkcjonuje na rynku. Badania dowodza, że opracowywane prognozy mają niewiele wspólnego z rzeczywistościa. Prognozowany popyt jest bardzo słabo skorelowany z faktycznym, a jeśli już, to negatywnie ${ }^{58}$. To podważa zasadność prowadzenia badań przed wprowadzeniem produktu na rynek i skłania do większej ostrożności przy kształtowaniu programów ubezpieczeń opartych na ich wynikach.

Jednocześnie jednak przegląd wyników badań pozwala zauważyć, że niezależnie od tego, czy badany był popyt hipotetyczny czy rzeczywisty, pewne prawidłowości co do istotności i kierunku oddziaływania niektórych czynników istnieją. Zasadniczo można stwierdzić, że ważną rolę odgrywa stosunek świadczenia do ceny i nie jest to wniosek zaskakujacy. Występuje jednak szereg czynników pozacenowych, które silnie mogą zmniejszać lub dynamizować popyt. Sa to ograniczenia w zakresie płynności finansowej gospodarstw, poziom zaufania do instytucji zaangażowanej w program, jak i do samego programu ubezpieczeniowego, wewnętrzne więzi pomiędzy potencjalnymi klientami czy doświadczenia w zakresie otrzymanych świadczeń ubezpieczeniowych w przeszłości.

Kraje, w których prowadzi się badania, należą niemalże w całości do krajów rozwijajacych się, które cechuje niski lub średni dochód przeciętny (przy czym poziom zróżnicowania jest wysoki). Przeciętna wielkość gospodarstwa jest mała, przetrwanie gospodarstw silnie zależne od warunków pogodowych, liczba lat edukacji prowadzącego gospodarstwo znacznie zróżnicowana ${ }^{59}$. Oferowane produkty mają charakter mikroubezpieczeń. Wydawać by się mogło, że takie uwarunkowania ekonomiczne i kulturowe znacznie ograniczają możliwość przenoszenia wniosków i aplikacji pewnych rozwiązań w odniesieniu do krajów rozwiniętych. Przykład Polski przeczy jednak takiemu stwierdzeniu. Tym, co jest wspólne dla wszystkich krajów, niezależnie od stopnia ich rozwoju gospodarczego, jest kluczowa rola zaufania do instytucji i do produktu ubezpieczeniowego oraz historia odszkodowawcza.

Pomimo szerokiego spektrum prowadzonych badań w odniesieniu do popytu na produkty indeksowe w rolnictwie wskazać można pewne „białe plamy”, obszary słabo rozpoznane. Jednym z nich jest problematyka ryzyka bazowego. Istotne jest zbadanie związków nie tylko pomiędzy poziomem ryzyka bazowego a zgłaszanym popytem, ale w szczególności pomiędzy subiektywnym postrzeganiem tego ryzyka a zakupem ubezpieczenia w danym i kolejnych okresach. Dodatkowo rozpoznanie mechanizmów i czynników, które wyjaśniałyby

${ }^{58}$ C. McIntosh et al., op. cit., s. 410.

59 S. Cole et al., The effectiveness of index-based micro-insurance in helping smallholders manage weather-related risks, London: EPPI-Centre, Social Science Research Unit, Institute of Education, University of London, London 2012, s. 22. 
powiązanie pomiędzy „obiektywnym” a „subiektywnym” ryzykiem bazowym jest elementem niezbędnym w procesie kształtowania zaufania do produktu. Badań wymagają także inne elementy pozacenowe, w tym w szczególności znaczenie tzw. analfabetyzmu finansowego.

Zidentyfikowanie czynników wpływających na popyt jest punktem wyjścia do budowania sprofilowanych programów ubezpieczeniowych. Nie wystarczy jednak sama znajomość elementów determinujących popyt, ale konieczne jest dodatkowo rozpoznanie skutków stosowania produktów indeksowych zarówno w kontekście nakładów, jak i wyników działalności gospodarstwa rolnego i - później - całego sektora rolnego. Ubezpieczenia mają bowiem charakter instrumentalny względem określonych celów mikro- i makroekonomicznych. Tego typu analizy, mające jak dotąd charakter szczątkowy, wyznaczaja kolejny obszar badawczy w dziedzinie ubezpieczeń oraz w praktyce zakładów ubezpieczeniowych, jak również w polityce resortów - rolnictwa i finansów.

dr Monika Kaczała

Uniwersytet Ekonomiczny w Poznaniu

monika.kaczala@ue.poznan.pl

\section{FACTORS DETERMINING THE DEMAND FOR INDEX-BASED CROP INSURANCE}

\section{Sum mary}

The main aim of this study is to identify factors determining the demand for index-based crop insurance. A systematic search of published and unpublished material relevant to demand for index insurance in developing countries and Poland has been conducted. It has been found that not only price factors (the premium level, subsidy vouchers or credit constrains) but also non-pricing factors (liquidity constraints, trust and financial literacy) could affect the demand significantly. These findings are relevant not only for scaling-up the index programs in developing countries, but also to the EU, where within the Common Agricultural Policy for 2014-2020, subsidies of index insurance have been allowed for the first time. 